\title{
Volume Optimization of a Combined System of LNT and SCR Catalysts Considering Economic Feasibility and De-NOx Performance
}

\author{
Choong-Kil Seo*† , Byung-Chul Choi** and Young-Kwon Kim***
}

(Received 14 August 2012, Revised 12 December 2012, Accepted 20 December 2012)

\begin{abstract}
The purpose of the study is carried out volume optimization of a combined system consisting of an LNT and SCR catalysts from the standpoint of its economic feasibility and de-NOx performance. Under the rich air-fuel ratio conditions for $5 \mathrm{~s}(\Phi=1.1), \mathrm{CO}, \mathrm{H}_{2}$ and THC were generated at levels of $4 \%, 1.2 \%$ and $110 \mathrm{ppmC}_{1}$, respectively. The $\mathrm{NOx}$ conversion of the $1+1$ combination was $5 \%$ lower than that of the $1.5+0.5$ combination, however the reduced volume of the LNT catalyst decreased the total cost by about $6 \%$. Therefore, the optimal volume ratio of the LNT and SCR catalysts was found to be the $1+1$ catalyst combination, which has the highest total score in the terms of an economic feasibility and the NOx performance.
\end{abstract}

Key Words : Diesel engine, Catalyst, NOx, LNT(Lean NOx Trap), SCR(Selective Catalytic Reduction)

\section{Introduction}

Regulations on both mobile and stationary sources of exhaust emissions have become progressively stringent in recent years as the problem of environmental pollution has considerably worsened due to the exhaust gases from vehicles as well as from industrial flue gas stacks. Above all, the exhaust emission standards for vehicles have become particularly strict ${ }^{1}$. As diesel engines have high power and good fuel economy as well as lower $\mathrm{CO}_{2}$ emissions, their market share is

*†Choong-Kil Seo(corresponding author) : Department of Automative \& Mechanical Engineering, Howon University. E-mail : ckseo@howon.ac.kr, Tel : 063-450-7215

**Byung-Chul Choi : School of Mechanical System Engineering, Chonnam National University.

***Young-Kwon Kim : Gwangju Center, Korea Automotive Technology Institute. increasing, not only in commercial vehicles, but also in passenger cars. Because of the characteristics of diesel combustion, however, NOx is generated in the localized high-temperature combustion regions and particulates are formed in the zone of diffusion combustion. The Lean NOx Trap (LNT) and urea-Selective Catalytic Reduction (SCR) catalysts and combinations of them have been developed for the after-treatment of the exhaust gas to reduce the NOx emissions from diesel vehicles ${ }^{2}$. The European Union (EU) recently announced the Euro 6 regulation for implementation from 2014. It limits NOx to below $0.08 \mathrm{~g} / \mathrm{km}$ and $\mathrm{NH}_{3}$ to below $10 \mathrm{ppm}$ for diesel passenger cars on the ECE (Economic Commission for Europe) and EUDC (Extra Urban Driving Cycle) driving cycle, and for heavy-duty diesel vehicles on the ETC (European Transient Cycle) and ESC (European Stationary Cycle) driving cycle $^{3)}$. A favorable 
after-treatment system to overcome NOx reduction and $\mathrm{NH}_{3}$ slip in the Euro 6 regulation is a combined system consisting of LNT and SCR catalysts, and this has been investigated by several groups $^{1,4-8)}$. Among them, some studies have been conducted to improve the de-NOx performance using two stages and reformer installation for a combined system of LNT and SCR catalysts $^{9-10)}$. Our previous studies examined the de-NOx performance according to the changes of the catalyst volume of a combined system of LNT and SCR catalysts by an experiment involving a model gas reaction ${ }^{1,7)}$.

Furthermore, the estimation of the de-NOx performance of the combined system of LNT and SCR catalysts has not been reported from the standpoint of its de-NOx performance and economic feasibility for practical applications. The purpose of the study is to derive the volume optimization of the combined system of LNT and SCR catalysts from the standpoint of its economic feasibility and de-NOx performance.

\section{Experimental setup and method}

The diesel oxidation catalyst (DOC), catalytic diesel particulate filter (CDPF) and LNT catalysts used in the engine experiment are commercial catalysts for vehicles. An SCR catalyst consisting of $\mathrm{Cu}-\mathrm{ZSM}-5-\mathrm{ZrO}_{2} \quad(2 \mathrm{wt} \%)$ was prepared by ourselves in the laboratory to improve the catalytic activity at low temperature. The $\mathrm{Cu}-\mathrm{ZSM}-5-\mathrm{ZrO}_{2}$ catalyst was prepared by the conventional liquid-phase ion-exchange method ${ }^{11)}$.

The supplier(DOC, CDPF and LNT) cannot be identified for protecting their confidentiality. The physical characteristics of the commercial catalysts as well as the specifications of $\mathrm{Cu}-\mathrm{ZSM}-5-\mathrm{ZrO}_{2}$ $(2 \mathrm{wt} \%)$ are shown in Tables 1 and 2 . In the single-cylinder engine experiment, an estimation of the de-NOx performance of the combined LNT and SCR system was carried out using the in-cylinder method to generate the reducing agent. The test engine is a common rail type single-cylinder diesel engine with a swept volume of $500 \mathrm{cc}$. The after-treatment system is composed of DOC + $\mathrm{CDPF}+\mathrm{LNT}+\mathrm{SCR}$. The experimental methods for volume optimization of LNT and SCR combined system were introduced in our previous study ${ }^{12)}$. Three LNT+SCR volume ratios were used, $1+1,1.5+0.5$ and $0.5+1.5$, as a variable for volume optimization(ex. 1+1, 500cc+500cc).

Table 1 Physical characteristics of after-treatment systems

\begin{tabular}{cccc}
\hline Catalyst & Composition & $\begin{array}{c}\text { Volume } \\
(\mathrm{cc})\end{array}$ & $\begin{array}{c}\text { Cell } \\
\text { density(cpsi) }\end{array}$ \\
\hline $\mathrm{DOC}$ & $\mathrm{Pt}, \mathrm{Pd} / \mathrm{Al}_{2} \mathrm{O}_{3}$ & 340 & 600 \\
$\mathrm{CDPF}$ & $\mathrm{SiC}$ & 640 & 300 \\
& & 500, & 600 \\
$\mathrm{LNT}$ & $\mathrm{Pt}-\mathrm{Ba} / \mathrm{Al}_{2} \mathrm{O}_{3}$ & 250 & \\
& $\mathrm{Cu}-\mathrm{ZSM} 5-$ & 500, & 400 \\
$\mathrm{SCR}$ & $\mathrm{ZrO}_{2}$ & 250 & 400 \\
\hline
\end{tabular}

Table 2 Specification of LNT and SCR catalysts

\begin{tabular}{ccccc}
\hline $\begin{array}{c}\text { Catal } \\
\text { yst }\end{array}$ & Components & $\begin{array}{c}\text { Relative } \\
\text { weights } \\
(\mathrm{wt} \%)\end{array}$ & $\begin{array}{c}\mathrm{BET} \\
\left(\mathrm{m}^{2} / \mathrm{g}\right)\end{array}$ & $\begin{array}{c}\text { Mean } \\
\text { pore } \\
\text { size } \\
(\mathrm{nm})\end{array}$ \\
\hline $\mathrm{LNT}$ & $\begin{array}{c}\mathrm{Pt} / \mathrm{Pd} / \mathrm{Rh} \\
(\mathrm{Ba} / \mathrm{Ce} / \mathrm{Zr})\end{array}$ & $\begin{array}{c}3.3 / 0.72 / 0 . \\
31(-)\end{array}$ & 36.15 & 11.82 \\
$\mathrm{SCR}$ & $\begin{array}{c}\mathrm{Cu}-\mathrm{ZSM}-5- \\
\mathrm{ZrO}_{2}\end{array}$ & $5 /(2)$ & 356 & 2.44 \\
\hline
\end{tabular}

Fuel penalty $(\%)=$

$$
\left[\mathrm{M}_{\mathrm{R}} \mathrm{T}_{\mathrm{L}}-\mathrm{M}_{\mathrm{L}} \mathrm{T}_{\mathrm{R}}\right] /\left[\mathrm{M}_{\mathrm{L}}\left(2 \mathrm{~T}_{\mathrm{R}}+60\right)\right] \times 100(\%) \cdots
$$

where $M_{R}$ is the mass of fuel injected at a rich air-fuel ratio, $M_{L}$ is the mass of fuel injected at a lean air-fuel ratio, $T_{R}$ is the time of fuel injection at the rich air-fuel ratio, and $T_{L}$ is the time of fuel injection at the lean air-fuel ratio. 


\section{Experimental results and discussion}

\subsection{Exhaust emissions from the combined system}

The evaluation of the de-NOx performance of the combined system of LNT and SCR catalysts $\left(\mathrm{Cu}-\mathrm{ZSM}-5-\mathrm{ZrO}_{2}(2 \mathrm{wt} \%)\right)$ in the single cylinder diesel engine was carried out with the consideration of the operating conditions of the engine. The diesel engine emitted 500ppm of NOx under medium load and speed conditions ${ }^{13)}$. Table 3 shows the concentrations of exhaust gases at lean and rich air-fuel ratios. This experiment was carried out for 10 minutes at each equivalence $\operatorname{ratio}(\Phi)$. It shows the average concentration of exhaust gases generated at the engine outlet without going through an after-treatment system. The concentrations of exhaust gases are as follows: $505 \mathrm{ppm}$ of $\mathrm{NOx}, 200 \mathrm{ppm}$ of $\mathrm{CO}, 60 \mathrm{ppmC}_{1}$ of THC, and $13 \%$ of $\mathrm{O}_{2}$. At a rich air-fuel ratio using the DEM (Delayed or Extended Main-injection) method, the concentration of NOx in the exhaust gas is $320 \mathrm{ppm}$ and this is reduced by approximately $35 \%$ compared to that at a lean air-fuel ratio, due to incomplete combustion when it is operated for $5 \mathrm{~s}$ with $\Phi$ of 1.1 . The concentration of major reducing agents $\left(\mathrm{CO}\right.$ and $\left.\mathrm{H}_{2}\right)$ simulated under the model gas experiment conditions are $4 \%$ of $\mathrm{CO}$ and $1.2 \%$ of $\mathrm{H}_{2}$.

Table 3 Specification of LNT and SCR catalysts

\begin{tabular}{ccccccc}
\hline$\phi$ & $\begin{array}{c}\mathrm{NOx} \\
(\mathrm{ppm})\end{array}$ & $\begin{array}{c}\mathrm{CO} \\
(\mathrm{ppm})\end{array}$ & $\begin{array}{c}\mathrm{THC} \\
\left(\mathrm{ppmC}_{1}\right)\end{array}$ & $\begin{array}{c}\mathrm{O}_{2} \\
(\%)\end{array}$ & $\begin{array}{c}\mathrm{CO}_{2} \\
(\%)\end{array}$ & $\begin{array}{c}\mathrm{H}_{2} \\
(\%)\end{array}$ \\
\hline $\begin{array}{l}\text { Lean } \\
(0.4)\end{array}$ & 505 & 200 & 60 & 13 & 6 & - \\
$\begin{array}{l}\text { Rich } \\
(1.1)\end{array}$ & 320 & 40,000 & 110 & 0.9 & 12 & 1.2 \\
\hline
\end{tabular}

Fig. 1 shows a schematic diagram of the $\mathrm{NH}_{3}$ generation and reduction reactions over the combined system of LNT and SCR catalysts. At the lean air-fuel ratio, the NOx which is stored in the $\mathrm{Ba}$ sites as nitrates react with the $\mathrm{H}_{2}$ reducing agent generated for a short time by the DEM method. When the $\mathrm{NH}_{3}$ partly participates in the reduction reaction, the $\mathrm{NH}_{3}$ slips at the rear of LNT catalyst, due to temperature decrease of catalyst, particle growth of the catalyst and reduced axial length of the catalyst. After the SCR catalyst equipped at the rear of the LNT selectively adsorbs $\mathrm{NH}_{3}$ among the various exhaust gases, it converts the $\mathrm{NOx}$ to $\mathrm{N}_{2}$.

Fig. 2 shows the NOx emission behaviors at the rear of the LNT and SCR catalysts while they were operated by the rich/lean air-fuel $\operatorname{ratio}(5 / 55 \mathrm{~s})$. Fig. 2(a) shows the characteristics of NOx reduction at the rear of the LNT and SCR catalysts for $55 \mathrm{~s}$ under the operating conditions of the lean air-fuel ratio after the reducing agent is injected for $5 \mathrm{~s}$.

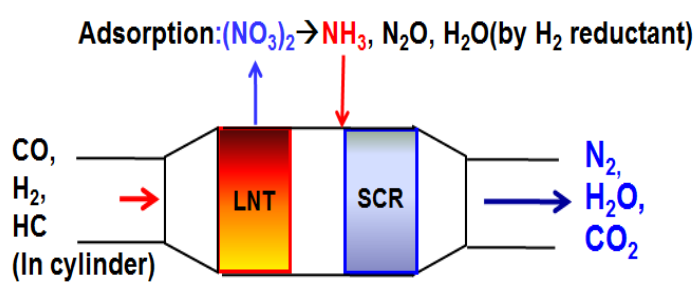

Fig. $1 \mathrm{NH}_{3}$ generation and reduction reaction over the combined system of LNT and SCR catalysts

The trend lines are shown at the average concentration of NOx according to the elapsed time in order to easily analyze the changes of the curve which repeatedly appears upon the adsorption of NOx. When the diesel fuel was injected for $5 \mathrm{~s}$ by the DEM method, the NOx on the Ba sites is released at a level of about 480ppm. The NOx conversion per cycle is decreased as the release of the NOx stored in the $\mathrm{Ba}$ sites increases. Looking 
at the overall trend, the average concentration of NOx at the rear of the SCR is lower than that at the rear of the LNT. The reason why the average concentration of NOx decreases at the rear of the SCR is that $\mathrm{NH}_{3}$ is generated by the $\mathrm{H}_{2}$ reducing agent and acts as reducing agent for the SCR. Fig. 2 (b) shows the NOx emission behaviors at engine out, the rear of DOC and the front of LNT when the reducing agent is supplied for $5 \mathrm{~s}$ at the rich air-fuel ratio. The difference of the NOx behaviors when the engine is operated at a lean air-fuel ratio for $55 \mathrm{~s}$ is only slight, and the concentration of NOx at engine out (at the front of DOC) when the engine is operated at a rich air-fuel ratio for $5 \mathrm{~S}$ ( $\Phi$ $=1.1$ ) is about $35 \%$ lower than that under lean
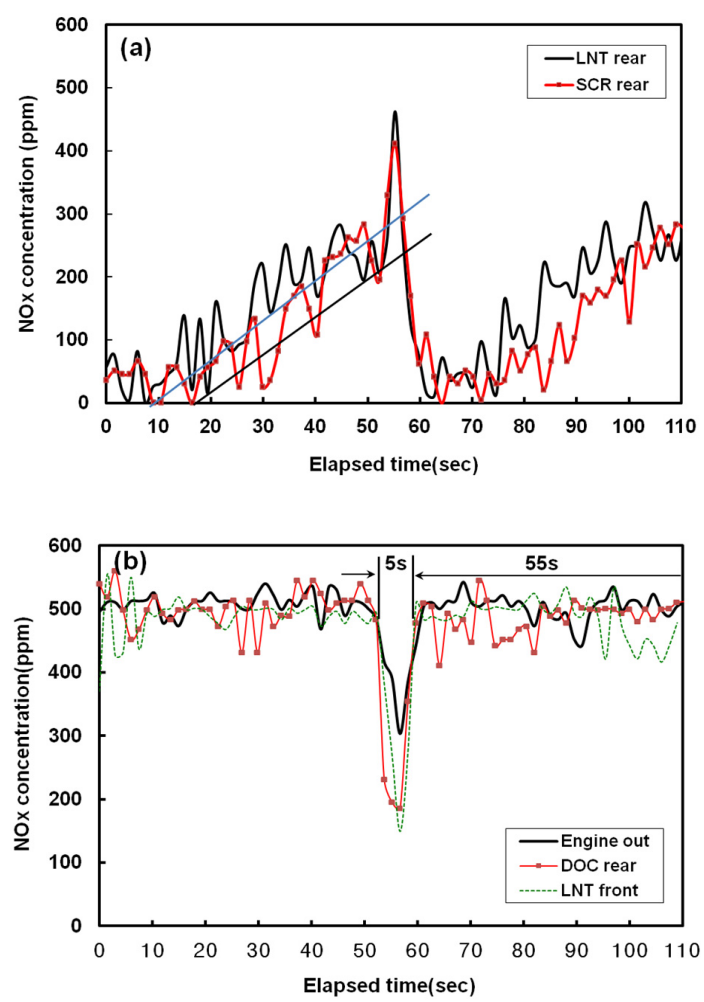

Fig. 2 NOx emission behaviors at the rear of catalysts during the rich/lean air-fuel ratio(5/55s) operating conditions. In addition, the level of NOx at the rear of DOC is decreased from 500ppm to about 170ppm. The reason for this is that the levels of reducing agents of the LNT catalyst, CO, $\mathrm{H}_{2}$ and THC were generated levels of $4 \%, 1.2 \%$ and $110 \mathrm{ppmC}_{1}$ under rich conditions, respectively, and these reducing agents participate in the reduction reaction with $\mathrm{NOx}$ over the DOC in the same manner as in the three-way catalyst of a gasoline engine.

\subsection{De-NOx performance of the combined system}

In our previous study $^{7)}$, the experiment of the model gas reaction was performed in the temperature range of $150-600{ }^{\circ} \mathrm{C}$ and the characteristics of $\mathrm{NOx}$ conversion and $\mathrm{NH}_{3}$ slip, as well as the $\mathrm{N}_{2} \mathrm{O}$ slip, which is a global warming gas, were investigated according to the volumetric combination of the LNT and SCR catalysts. We investigated the optimal catalyst ratio of the LNT(commercial) and SCR catalysts in a single cylinder engine experiment. At this point, a catalyst volume of $500 \mathrm{cc}$ is assumed to be 1 .

Fig. 3 shows the NOx conversion and CO slip at the rear of the SCR under lean/rich conditions of $55 / 5 \mathrm{~s}$ according to three catalyst combinations $(1.5+0.5,1+1,0.5+1.5)$ of the combined system of LNT and SCR catalysts. All of the data for the different combinations was compared to that of the LNT catalyst alone. In this experiment, an exhaust gas temperature at the front of LNT catalyst was $330^{\circ} \mathrm{C}$. Fig. 3 (a) shows that the NOx conversion rate of the LNT catalyst and the combined system of $\operatorname{LNT}(0.5)+\operatorname{SCR}(1.5)$ catalysts are $41 \%$ and $43 \%$, respectively. The NOx conversion of the $0.5+1.5$ combination is lower than those of the other combinations, because the NOx storage capacity is reduced, due to reduced volume of the LNT catalyst. 

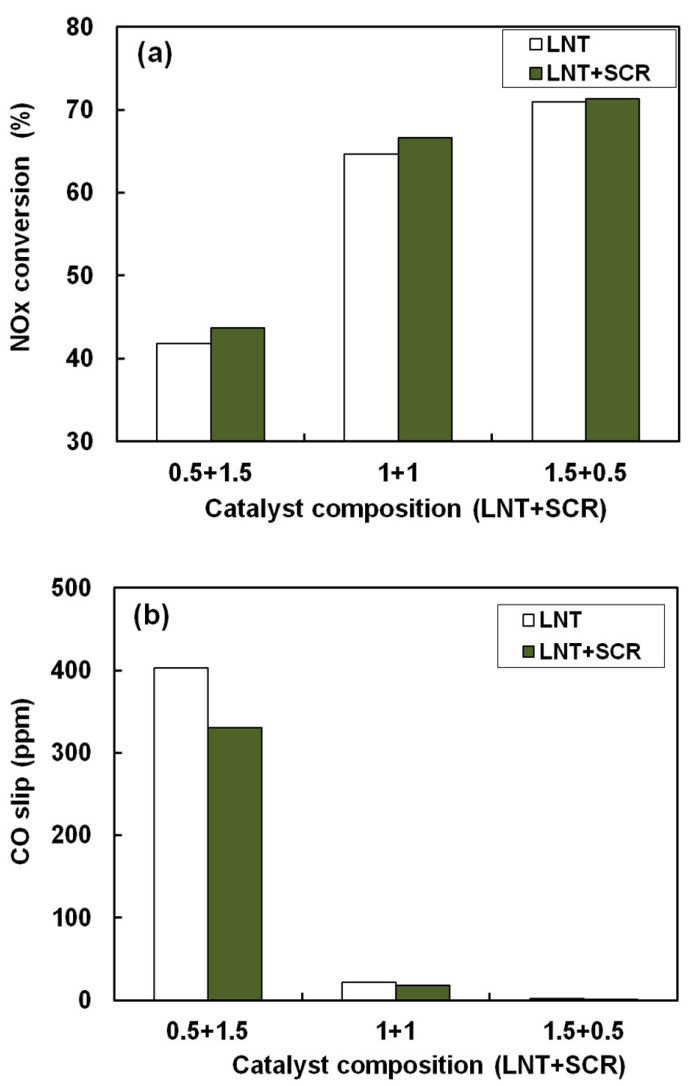

Fig. 3 NOx conversion (a) and CO slip (b) according to volume combination of the combined system of LNT and SCR catalysts

In fig. 3(b), the $\mathrm{CO}$ slip of the $0.5+1.5$ combination is very high at the rear of the LNT. The reason for this is that the NOx storage capacity is small, but the remaining $\mathrm{CO}$ slips after it participates in NOx reduction reaction with the supply of a large amount of the reducing agent, $\mathrm{CO}(4 \%)$. In addition, the NOx conversion of the $0.5+1.5$ combination is negligible compared to that of the LNT catalyst alone. The NOx conversions of the LNT alone and the $1+1$ combination are $65 \%$ and $67 \%$, respectively. If the volume of the LNT catalyst is increased, the NOx storage capacity is increased. Thus, the NOx conversion is improved by about $24 \%$ compared to that of the $0.5+1.5$ combination. It also shows that the $\mathrm{CO}$ slip is 17 ppm at the rear of the SCR. The NOx conversion of the combined system of LNT and SCR is improved by about $2 \%$ compared to the LNT alone. In fig. 3 (b), the $\mathrm{CO}$ slips with the $0.5+1.5$ and $1+1$ combinations tend to be reduced by about $19 \%$ compared to the LNT alone. The reason for this is that the $\mathrm{Cu}-\mathrm{ZSM}-5-\mathrm{ZrO}_{2}(2 \mathrm{wt} \%) \mathrm{SCR}$ catalyst oxidizes the $\mathrm{CO}$ to $\mathrm{CO}_{2}$. In the case of the $1.5+0.5$ combination system, although the volume of the LNT catalyst is increased by $50 \%$, the NOx conversion is not increased substantially. As shown in fig. 3(b), no $\mathrm{CO}$ slip is detected in the case of the $1.5+0.5$ combination. If the volume of the LNT catalyst is increased and a larger amount of NOx can be stored over the LNT catalyst, then the NOx conversion is increased. However, the improvement of the NOx conversion is not great, because a larger amount of reductants is not supplied.

\subsection{Economic feasibility of the combined system of LNT and SCR catalysts}

The economic feasibility of the combined system of LNT and SCR catalysts was evaluated considering the NOx conversion and the emission characteristics of the various harmful substances of the combination systems, which are based on the results of the model gas experiment of our previous studies $^{1,7)}$ and the single-cylinder engine experiment.

Table 4 shows the results of the evaluation of the economic feasibility and de-NOx performance for the combined system of LNT and SCR catalysts. In Table 4, the score of the parameters is estimated as follows. The cost score about (a) prices of the basic after-treatment system for de-NOx is 100 points. In terms of economic, the score is subtracted from 100 points as the increase ratio because cost increase ratio is losses. The score of the (b), (e) NOx conversion is equal to 
Table 4 Evalution of economic feasibility for the combined system of LNT and SCR catalysts

\begin{tabular}{|c|c|c|c|c|}
\hline $\mathrm{LNT}+\mathrm{SCR}$ ratio parameter & $\begin{array}{l}1.5+ \\
0.5\end{array}$ & $\begin{array}{l}1.0+ \\
1.0\end{array}$ & $\begin{array}{c}0.5+ \\
1.5\end{array}$ & Valuation basis \\
\hline $\begin{array}{l}\text { (a) Prices }(\$) \\
\text { Cost increase ratio(\%) } \\
\text { (score) }\end{array}$ & $\begin{array}{c}2,688 \\
17.6 \\
(82.4)\end{array}$ & $\begin{array}{c}2,544 \\
11.7 \\
(88.3)\end{array}$ & $\begin{array}{l}2,420 \\
5.8 \\
(94.2)\end{array}$ & $\begin{array}{c}(\mathrm{DOC}+\mathrm{DPF}+ \\
\mathrm{LNT}): 2,286 \text { basis(by Table } 5) \\
\text { score }=100 \text {-cost increase ratio }\end{array}$ \\
\hline $\begin{array}{l}\text { (b) NOx conv.(\%) } \\
\text { by model gas experiment } \\
\text { (score) }\end{array}$ & $\begin{array}{c}54 \\
(54)\end{array}$ & $\begin{array}{c}49 \\
(49)\end{array}$ & $\begin{array}{l}39 \\
(39)\end{array}$ & $\begin{array}{l}\text { NOx conv. }(\%) \text { at } 150-600^{\circ} \mathrm{C} \\
\text { score=NOx conv. }(\%)\end{array}$ \\
\hline $\begin{array}{c}\text { (c) } \mathrm{NH}_{3} \text { slip(ppm) by model } \\
\text { gas experiment } \\
\text { (score) }\end{array}$ & $\begin{array}{c}5.72 \\
(42.8)\end{array}$ & $\begin{array}{l}0.39 \\
(96)\end{array}$ & $\begin{array}{l}2.7 \\
(73)\end{array}$ & $\begin{array}{c}<10 \mathrm{ppm} \text { : Euro } 6(\mathrm{HD})^{2)} \\
\text { score }=0 \mathrm{ppm}(100) \text {-concent.(ppm }) \times \\
10\end{array}$ \\
\hline $\begin{array}{l}\text { (d) } \mathrm{N}_{2} \mathrm{O} \text { slip(ppm) by } \\
\text { model gas experiment } \\
\text { (score) }\end{array}$ & $\begin{array}{c}5 \\
(45)\end{array}$ & $\begin{array}{c}2.74 \\
(47.3)\end{array}$ & $\begin{array}{l}1.02 \\
(49)\end{array}$ & $\begin{aligned} & <50 \mathrm{ppm}: \mathrm{ACGIH}^{16)} \\
\text { score} & =0 \mathrm{ppm}(50) \text {-concent. }(\mathrm{ppm})\end{aligned}$ \\
\hline $\begin{array}{l}\text { (e) NOx conv.(\%) by } \\
\text { engine experiment } \\
\text { (score) }\end{array}$ & $\begin{array}{c}71 \\
(71)\end{array}$ & $\begin{array}{c}67 \\
(67)\end{array}$ & $\begin{array}{c}44 \\
(44)\end{array}$ & $\begin{array}{l}\text { NOx conv. of LNT at } 330^{\circ} \mathrm{C} \\
\text { score=NOx conv. }(\%)\end{array}$ \\
\hline $\begin{array}{l}\text { (f) CO slip(ppm) by engine } \\
\text { experiment } \\
\text { (score) }\end{array}$ & $\begin{array}{c}0.9 \\
(49.1)\end{array}$ & $\begin{array}{l}17.7 \\
(32.5)\end{array}$ & $\begin{array}{l}330 \\
(0)\end{array}$ & $\begin{array}{l}<50 \text { ppm:U.S OSHA exposure } \\
\text { limit)(PEL) } \\
\text { score }=0 \text { ppm }(50) \text {-concent. }(\mathrm{ppm})\end{array}$ \\
\hline Total score & 344.3 & 380.1 & 299.2 & \\
\hline
\end{tabular}

*(b)-(d) technical data : reference ${ }^{7}$

the NOx conversion rate. In the case of the score of (c) $\mathrm{NH}_{3}$ slip, if the score for an $\mathrm{NH}_{3}$ concentration of $0 \mathrm{ppm}$ is 100 points, that for an $\mathrm{NH}_{3}$ concentration of $10 \mathrm{ppm}$ or more is 0 points, and the score for intermediate concentrations is proportional to the concentration. In Table 4, the weight factor of each item is assigned a value of 100 and those of $\mathrm{N}_{2} \mathrm{O}$ and $\mathrm{CO}$ are assigned a value of $1 / 2(=50)$ that of the other items, because $\mathrm{N}_{2} \mathrm{O}$ is less important than the other gases and $\mathrm{CO}$ has high activity on the catalyst.

If the score (d) for $\mathrm{N}_{2} \mathrm{O}$ concentration of $0 \mathrm{ppm}$ is 100points, that for concentration of $50 \mathrm{ppm}$ or more is 0 points, and the score for intermediate concentrations is proportional to the concentration. In case of the score (f) for $\mathrm{CO}$ concentration, $0 \mathrm{ppm}$ concentration is 100points, that for concentration of $50 \mathrm{ppm}$ or more is 0 points, and the score for intermediate concentrations is proportional to the concentration.
Table 5 is the price of the basic catalyst units required to perform the economic feasibility study of the combination system. Here, the price used for the after-treatment system of DOC, DPF, and LNT was taken to be the price of mass production of the catalyst manufacturer. It is calculated for the combined system of LNT and SCR catalysts with the displacement volume of $2 \mathrm{~L}$ diesel passenger car and the volume ratio (catalyst/engine displacement) refers to the results in the literatures ${ }^{5,9,13-15)}$. The

Table 5 Evalution of economic feasibility for the combined system of LNT and SCR catalysts

\begin{tabular}{cccccc}
\hline Catalysts & $\begin{array}{c}\mathrm{Pt} \\
(\mathrm{g} / \mathrm{L})^{*_{1}} \\
\text { loading }\end{array}$ & $\begin{array}{c}\text { Price } \\
(\$ / \mathrm{L})\end{array}$ & $\begin{array}{c}\text { Vol. } \\
\text { ratio/ } \\
\text { engine } \\
\text { disp. }\end{array}$ & $\begin{array}{c}\text { Vol. } \\
(\mathrm{L})\end{array}$ & $\begin{array}{c}\text { Total } \\
\text { cost } \\
(\$)\end{array}$ \\
\hline DOC & 3.3 & 268 & 0.6 & 1.2 & 321 \\
DPF $^{* 2}$ & 1.5 & 446 & 1.6 & 3.2 & 1,429 \\
LNT & 3.1 & 268 & 1 & 2 & 536 \\
SCR & - & 134 & 1 & 2 & 268 \\
\hline
\end{tabular}


score is calculated by subtracting the rate from 100 , because the cost increase is considered to be the loss from the economic viewpoint based on the cost of the basic configuration of the DOC+ CDPF+LNT system. As mentioned above, the scores for each item are used for the evaluation of the economic feasibility of the catalyst based on the results of the model gas experiment ${ }^{7)}$ and of the single-cylinder engine experiment. the cost increase of the $0.5+1.5$ combination is about $5.8 \%$ higher than that of the basic configuration of the DOC $+\mathrm{CDPF}+\mathrm{LNT}$ system. The cost increase of the $0.5+1.5$ combination is lower than that of the others, but it is not an effective increase due to the poor NOx conversion. The NOx conversion of the $1+1$ combination is $5 \%$ lower than that of the $1.5+0.5$ combination, however the reduced volume of the LNT catalyst decreases the total cost by about $6 \%$. Therefore, the optimal volume ratio of the LNT and SCR catalysts is $1+1$ combination, which has the highest total score.

\section{Conclusions}

The purpose of the study is carried out volume optimization of a combined system consisting of an LNT and SCR catalysts from the standpoint of its economic feasibility and de-NOx performance. Under the rich air-fuel ratio conditions for $5 \mathrm{~s}(\Phi$ $=1.1), \mathrm{CO}, \mathrm{H}_{2}$ and THC were generated at levels of $4 \%, 1.2 \%$ and $110 \mathrm{ppmC}_{1}$, respectively. The NOx conversion of the $1+1$ combination is $5 \%$ lower than that of the $1.5+0.5$ combination, however the reduced volume of the LNT catalyst decreases the total cost by about $6 \%$. Therefore, the optimal volume ratio of the LNT and SCR catalysts was the $1+1$ combination, which has the highest total score. In conclusion, the $1+1$ volume combination was found to be the optimal volume ratio considering the economic feasibility and de-NOx performance of the combined system of LNT and SCR catalysts.

\section{Acknowledgement}

This research was supported by the academic research expense in the howon university.

\section{References}

1. C. K. Seo, H. N. Kim, B. C. Choi, M. T. Lim, C. H. Lee and C. B. Lee, 2011, "De-NOx characteristics of a combined system of LNT and SCR catalysts according to hydrothermal aging and sulfur poisoning", Catalysis Today. Vol. 164. pp. 507-514.

2. C. K. Seo, H. N. Kim and B. C. Choi, 2010, "Characteristics of Adsorption, Desorption of Exhaust Gases and Deactivation of LNT and SCR Catalysts for Diesel Vehicles", Journal of the Korea Society For Power System, Vol 14. pp. 13-19.

3. Official Journal of the European Union, Regulation (EC) No 595/2009. July 18.

4. R. Snow, D. Dobson, R. Hammerle and S. Katare, "Robustness of a LNT-SCR System to Aging Protocol", SAE Papers No. 200701-0469.

5. J. Wang, Y. JI, Z. He, M. Crocker, M. Dearth and R. McCabe, "A non- $\mathrm{NH}_{3}$ pathway for $\mathrm{NOx}$ conversion in coupled LNT-SCR system", SAE Papers No, 2010-01-0305.

6. P. Forzatti and L. Lietti, 2010, "The reduction of NOx stored on LNT and combined LNT-SCR systems, Catalysis Today. Vol. 155. pp. 131-139.

7. C. K. Seo, H. N. Kim, B. C. Choi and M. T. Lim, 2011, "The optimal volume of a combined system of LNT and SCR catalysts", J. Ing. Eng. Chem. Vol. 17, pp. 382-385. 
8. S. Y. Park, H. N. Kim and B. C. Choi, 2010, "Effective parameters for DME steam reforming catalysts for the formation of $\mathrm{H}_{2}$ and $\mathrm{CO}, \mathrm{J}$. Ing. Eng. Chem. Vol. 16. pp. 734-740.

9. L. Xu, R. McCabe, M. Dearth and W. Ruona, "Laboratory and vehicle demonstration of "2nd-generation" LNT+in-situ SCR diesel NOx emission control systems", SAE Papers No, 2010-01-0305.

10. C. Chimmer, "Transient on-road emission reduction of an LNT+SCR after-treatment system", SAE Papers No. 2008-01-2641.

11. C. K. Seo, B. C. Choi, H. N. Kim, C. H. Lee and C. B. Lee, 2012, "Effect of $\mathrm{ZrO}_{2}$ addition on de-NOx performance of Cu-ZSM-5 for SCR catalyst", Chem. Eng. J., Vol. 191, pp. 331-340.

12. C. K. Seo, 2012, "Optimization of an LNT-SCR combined system to de-NOx the diesel engine exhasut gas". dissertation for the degree of the Ph. D., Chonnam National University, pp. 54-55.

13. B. West, S. Huff, J. Parks, S. Lewis, J. S. Choi W. Partride and J. Story, "Assessing reductant chemistry during in-cylinder regeneration of diesel lean NOx traps, SAE Papers No. 2004-01-3023.

14. J. Parks and V. Prikhodko, "Ammonia production and utilization in a hybrid LNT+SCR system, SAE Papers No. 2009-01-2739.

15. M. F. Hsieh and J. Wang, 2011, "Sliding-mode observer for urea-selective catalytic reduction (SCR) mid-catalyst ammonia concentration estimation" Int. J. Automo. Tech. Vol. 12. pp. 351-358.

16. B. C. Choi, 2001, "Technologies for emission after-treatment", Baro Press Co., p. 51.

17. http://www.dieselnet.com. 